\title{
Recurrent Ovarian Germ Cell Tumor
}

National Cancer Institute

\section{Source}

National Cancer Institute. Recurrent Ovarian Germ Cell Tumor. NCI Thesaurus. Code C8087.

The reemergence of ovarian germ cell tumor after a period of remission. 